\title{
Comparing the Concept of Ideal State Through the Lens of al-Farabi's and Augustine's Perspectives
}

\author{
Sudarman \\ Universitas Islam Neberi Raden Intan Lampung \\ sudarman@radenintan.ac.id
}

\begin{abstract}
This research is a comparative analysis over the concept of an ideal state according to the perspective of a Muslim philosopher, al-Farabi and that of a Christian philosopher, Augustine. It is an interfaith study that is based on a library research. The main data are collected through the book of Arā 'Ahl al-Madinnah al-Fādilah by al-Farabi and The City of God, by Augustinus, before they are analyzed with a hermeneutic approach. It argues that there are some similarities between al-Farabi's and Augustine's thoughts on the concept of ideal state, as well as a few differences. According to al-Farabi, an ideal state is the one that is led by a prophet or a philosopher, because, like the heart in a human body, the leader occupies a central position and is highly decisive. An ideal state according to Augustine refers to the concept of the city of God or the heavenly city, which is resided by innocent people, or sinners who have received God's repentance. In this regards, the opposite of the City of God is the City of Man, in which all sinners are living their lives.
\end{abstract}

Keywords : al-Farabi, Augustine, ideal state, comparative analysis

Abstrak : Penelitian ini merupakan analisis komparatif atas konsep negara ideal menurut pandangan filsuf Muslim al-Farabi dan filsuf Kristen, Agustinus. Ini adalah studi lintas agama yang didasarkan pada penelitian perpustakaan. Data utama dikumpulkan melalui kitab Arā 'Ahl alMadinah al-Fādilah karya al-Farabi dan The City of God karya Agustinus, sebelum dianalisis dengan pendekatan hermeneutik. Penelitian ini berargumen bahwa ada beberapa kesamaan antara pemikiran al-Farabi dan Agustinus tentang konsep negara ideal, serta beberapa perbedaan. Menurut al-Farabi, negara ideal adalah yang 
dipimpin oleh seorang nabi atau filsuf, karena seperti hati dalam tubuh manusia, pemimpin menempati posisi sentral dan sangat menentukan. Keadaan ideal menurut Agustinus mengacu pada konsep kota Tuhan atau kota surgawi, yang dihuni oleh orang-orang yang tidak bersalah, atau orang-orang berdosa yang telah menerima pertobatan Tuhan. Dalam hal ini, kebalikan dari Kota Tuhan adalah Kota Manusia, di mana semua orang berdosa menjalani hidup mereka.

Kata Kunci : al-Farabi, Agustinus, Negara Ideal, Analisis Perbandingan

\section{A. Introduction}

Ideas about state and its forms have always been a topic of high interest among Western and Muslim scholars alike. This is because modern people need the government and the state to create a just and prosperous society. Discussion about the state and government has now regained its momentum, as modern people are encountered with anomalies about state formats, as a result of globalization and the new industrial revolution of 4.0.

Debates about an ideal state are not a novel issue, but had been done among Greek philosophers. Plato, for example, argued that an ideal state is one that is able to create happiness for its citizens. ${ }^{1}$ Therefore state leaders must learn and comprehend correctly these virtues, and try their best to implement the good virtues and discard the bad ones. Plato's concept of the ideal state is a commentary of Socrates's idea of the state. Plato argued that state will continue to exist and develop because it is a human's basic need. Humans are unable to fulfill individually their needs and desires. They have to cooperate with others to comply their daily needs: a unity of people who have the same needs and standpoints, which is called society or the state. ${ }^{2}$

Aristotle opines that a state is a combination or a collection of families. A proper state is begun with the creation of a good family. A happy state, a manifestation of shared happiness, is obtained when families in that state are a good family, and that a good family is consisted of good individuals. State is an accumulation of people who are in need of each other,

${ }^{1}$ C.S.T Kansil, Ilmu Negara Umum dan Indonesia (Jakarta: Pradnya Paramita, 2001), 133.

${ }^{2}$ Ibid,. 
and are willing to contribute to each other, because they shared the same objectives. $^{3}$

In both Islamic and Christian traditions, al-Farabi and Augustine are known as one of the most prominent figures in philosophy, whose thoughts on the formation of an ideal state are worth comparing, as they shared some similarities as well as differences. Al-Farabi, who in Medieval Latin texts is referred to as Alfarabius or Avennaser, is one of the prominent Muslim philosophers, while Augustine is the famous ancient Church Father.

According to al-Farabi, an ideal state, which he called al-Madinah al-Fādilah, or the excellent or virtuous city, is a key factor to realize an ideal nation. An ideal world is the world upon which ideal nations are established. An ideal state, according to al-Farabi, is the state in which its citizens work together to achieve the true happiness. ${ }^{4}$ The opposite of an ideal state is 1 ) an ignorant city; 2) a wicked city; 3) an immoral city; 4) an erring city. AlFarabi claimed that an ideal state might be inhibited by immoral citizens, whom he called, 5) a plant that is wicked and dangerous (the weeds). ${ }^{5}$

Augustine has divided the state into two types: the city of man and the city of God. Both cities have their own characteristics, which come down all the ways to human's very first conditions. "The city of man" is characterized by its citizens who glorify themselves, and "the city of God" is by its citizens who glorify the God. ${ }^{6}$ Both cities will continue to grow and develop, all with their own dynamics and experiences: in the end their difference will become clear as a crystal.

An exploration into the concept of an ideal state is not something new. Yet, by exploring two different perspectives on this topic, a new and clearer understanding about the concept of an ideal state will be provided, and both the similarities and differences about this topic in both Islamic and Christian traditions become clearer. This paper is based on a library

${ }^{3}$ Ibid,.

${ }^{4}$ Richard Walzer, "Greek into Arabic: Essays on Islamic Philosophy," the School of Oriental and African Studies, 1962, 244.

${ }^{5}$ Abu Nashr Muhammad bin Muhammad bin Tarkhan bin Auzalagh al-Farabi, Arā' Ahl al-Madīnah al-Fādilah. (Mesir: al-Azhar, t.t.), 17.

${ }^{6}$ Gonzales L. Justo, A History of Christian Thought (Nashville: Abingdon, 1971), 52. 
research. Its main data are sourced from books and journal articles, which related to the perspectives of both Al-Farabi and Augustine on the concept of an ideal state.

\section{B. Conceptual Framework}

Al-Farabi's and Augustine's thoughts on the concept of an ideal state have both differences and similarities, which are relevant to be reexamined in our contexts because as such will help us better understand how to improve our organization of a state in the contemporary era. The concept of an ideal state according to the perspective of al-Farabi and Augustine can be depicted as follows.

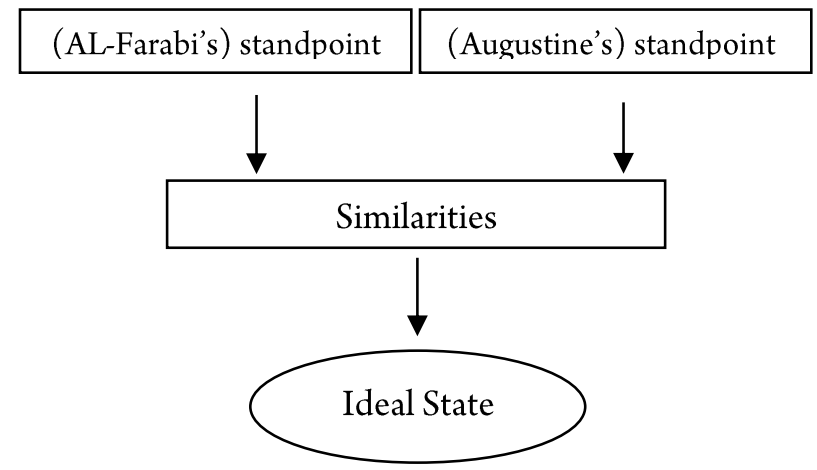

Figure 1. The Conceptual Frameeork

Scholars have maintained different opinions about society and the state, as well as about their relationship in social-life realities. Some of them have put the state in a stronger place than that of the society, while the other placed the society in a stronger position than that of the state. Considering this difference of opinion, it is necessary to further explore the thoughts of al-Farabi and Augustine regarding the concept of society and state and how the two are interrelated.

1. Conception of State in Western and Islamic Perspectives

Scholars have formulated various definitions of a state, despite substantially, their definitions suggest similar meanings. Roger H. Soltau maintains that state is both an agency and authority that regulate and control 
common problems in and on the behalf of society. ${ }^{7}$ State is an organization of a particular area, which has a legitimate power to force all groups in that area, in accordance to their shared ideals and objectives.

A tendency to force is one of the main characters of a state. This character has been emphasized by Max Weber and Robert M. MacIver in their definition of state. In fact, it is legal for a state, according to them, to monopoly the use of physical violence in a given area. ${ }^{8}$

Adam Muller defined the state by referring to its basic and simple forms. According to him, the formation of a state is equivalent to the formation of a family. The state is an extension of the family. Like in a family, every state has its own conflicts that men of that state must overcome. ${ }^{9}$

In his Politics, Aristotle specified several forms of an ideal state, all of which have many to do with morality. A good state is a state that succeeds to achieve its goals. Likewise, a bad state is the one that is fail to attain its objectives. According to Aristotle, state can take various formats. There are states whose forms are based on the number of their leaders. Some states are led by one leader, the other by several leaders, and the rest by many leaders. Second, there are states whose forms are based on their objectives, either for public welfare or for authorities' interests. State of this format may include monarchy, tyranny, aristocracy, and oligarchy models. ${ }^{10}$

Enlightenment philosophers such as Thomas Hobbes, John Locke, or Jacques Rousseau had much discussed about the state and its formation. They had fought so much against the domination of religion, especially Catholicism, that their theories had taken a distance from religious traditions, even though major religions such as Islam, Hinduism, and Buddhism, had long existed before they lived. ${ }^{11}$ The influences of Enlightenment philosophers are observable in the thoughts of European

\footnotetext{
${ }^{7}$ Roger H. Soltau, An Introduction to Politics (London: longmans, 1961), 1.

${ }^{8}$ Max Weber, Hans Heinrich Gerth, and C. Wright Mills, From Max Weber: Essays in Sociology (New York: Oxford University Press, 1955), 78; Compare with Robert M. Maclver, The Modern State (London: Oxford University Press, 1955), 22.

${ }^{9}$ Frans Magnis Suseno, Pijar-Pijar Filsafat, dari Gatholoco ke Filsafat Perempuan, dari Adam Muller ke Post Modernisme (Yogyakarta: Kanisius, 2005), 63.

${ }^{10}$ Ahmad Suhelmi, Pemikiran Politik Barat (Jakarta: Gramedia, 2007), 47.

${ }^{11}$ Abdul Aziz, Chiefdom Madinah: Salah Paham Negara Islam (Jakarta: Pustaka Alfabet, 2011), 14.
} 
intellectuals of the modern era. They don't base their thoughts about the state on any religious traditions. Bryan Turner, for example, barred his thoughts on the concept of state from any religious influences. As such is perhaps due to the rising popularity of secularization, which is seen as the marker of the modern era.

According to Western thinkers, it all started from a city (polis) in its simplest form, which later would develop into what is called a state, that is, a unit that facilitates the occurrence of technological advance, industrialization, trading activities, common senses, and border expansion. This unit in its turn would become a nation-state.

The above idea is different from sociologists' arguments. Marx Weber offered a descriptive-explanatory of the state. This kind of thinking is also seen in Karl Marx, Norbert Elias, and anthropologists such as Lewis H. Morgan or Julian Steward. ${ }^{12}$

In contrast to western thinkers, almost all Muslim intellectuals constructed their concept of the state on the basis of religious tradition, that is, Islam. A few of them believed that Islam as religion has provided complete concepts of life, including the concept of the state. Ibn Abi Rabi' argues that in living their lives, human beings are dependent upon each other, leading them to unite and establish a state. He argues that caliphate, in which throne of the state is based on the lineage system, is the best form of state. ${ }^{13}$

Al-Mawardi and Ibn Khaldun also talked about caliphate. AlMaududi argued that the state cannot be separated from the concept of alIlah and al-Rabb, interpreted as giving all law-making rights only to God. $\mathrm{He}$ rejected the concept of democracy concept because it allows common people to bear the rights of law-making. ${ }^{14}$

In Indonesia, one figure who has paid serious attention to the conceptualization of state is Muhammad Natsir. He maintained that Islam is not only a private religion which largely concerns about humans'

\section{${ }^{12}$ Abdul Aziz, 15.}

${ }^{13}$ Syamsul Bakri, “Agama, Persoalan Sosial, dan Krisis Moral,” Komunikasi: Jurnal Dakwah dan Komunikasi3, no. 1 (t.t.): 42.

${ }^{14}$ Abu al-A'la Al Maududi, Nazhariyyah al-Islam al-Siyasiyyah (Kuwait: Maktabah al-Manar, t.t.), 1-15. 
relationship with God, but also a public religion that governs all aspects of human life, including politics and state affairs. ${ }^{15}$

Generally, based on our discussion above, the conception of state is divided into two theories, namely the speculative theory and the historical or evolutional theory. The speculative theory consists of social interaction theory, theocratic theory, power theory, patriarchal theory, organic theory, expiration theory, and other theories that are based on idealistic perspectives.

\section{State Objectives}

State establishment has many to do with the fact that human beings are in need of each other. Basic needs in life are difficult to fulfill if there is no mutual relationship among individuals in society. That is why, in every society and state, the occurrence of mutual relationships between members of the state has always been inevitable. Because of this, all citizens of a given state are responsible to preserve the unity and integrity of their state.

The purpose of establishing a state is to achieve welfare and happiness. According to Budiarjo, a state is established to create people's welfare (bonum publicum, or the common good, or the commonwealth). ${ }^{16}$

In order to realize the state objectives, elements of the state have to function well. There are at least four major functions of the state. They are, firstly, to implement law and order; secondly, to strive for the welfare and prosperity of the people, thirdly, to perform a defense, and fourthly, to uphold justice. ${ }^{17}$ Likewise, Charles E. Merriam added that there is another crucial function of the state, that is, freedom. According to him, the function of the state includes five things, namely external security, internal order, justice, public welfare, and freedom. ${ }^{18}$

3. Relationship between Society and State

Many theories have emerged to discuss the relationship between society and the state. In general, they can be summarized into two types: one

${ }^{15}$ Muhammad Natsir, Agama dan Negara dalam Perspektif Islam (Jakarta: Dewan Dakwah Islamiyah Indonesia, 2001), 83.

${ }^{16}$ Miriam Budiarjo, Dasar-dasar Ilmu Politik (Jakarta: Gramedia, 2001), 45.

${ }^{17}$ Ibid., 46.

18 Ismail Hasani, "Paradoks Konstitusional Jaminan Kebebasan Beragama/Berkeyakinan,” Mimbar: Jurnal Agama dan Budaya, Vol. 26, no. 3 (2009): 385. 
type that place the state over the society and the other that views the society as a stronger notion than the state.

a. Society as a Sub

b. ordinate of the Sate

Plato and Aristotle argued that a state requires an absolute power. This power is needed in order to educate and control the citizens. ${ }^{19}$ In line with Plato and Aristotle, Thomas Hobbes (1588-1679) stated that every state needs to have a full power, because otherwise it would face serious problems coming from its citizens' conflicting interests. ${ }^{20}$

The idea that a state should have an immense amount of power was first argued by Hegel (1770-1831) when he developed his philosophy of dialectics between the ideal and the real. Hegel argued that the state has the right to impose the will of its entire citizens in order to realize what is deemed the ideal and the universal. By obeying the state, citizens can avoid their selfishness for smaller interests, and at the same time, the state can create a good living-together. ${ }^{21}$

1) Theory of Divinity

Theory of divinity perceives that sovereignty comes from God. A ruler becomes powerful only because God has presented His power upon him/her. In medieval times, debates about sources of legitimacy were already heated. Most scholars of that time opined that a state must submit to the sovereignty of the (Catholic) Church. ${ }^{22}$ Thomas Aquinas, one of the famous figures of the medieval era, argued that life in this world is structured upon the eternal law (Lex Aeterna) and the natural law (Lex Naturalis). ${ }^{23}$

${ }^{19}$ Amroeni Drajat, Suhrawardi: Kritik Falsafah Parepatetik (Yogyakarta: LKiS, 2005), 85; and see Inson and Ute Schumacher, "Government Policy and Human Development Evidence from Developing Countries," Journal of The Third World Studies XII, no. 2 (1995): 247.

${ }^{20}$ Gladstone Hutchinson \& Ute Schumacher, "Government Policy and Human Development Evidence from Developping Countries”, Journal of Third World Studies, Volume XII, no. 2, 1995.

${ }^{21}$ Frans Magnis Suseno, Kuasa dan Moral (Jakarta: Gramedia, 2000), 10.

${ }^{22}$ Arief Budiman, Teori Negara: Negara, Ideologi dan Kedaulatan (Jakarta: Gramedia, 1996), 10.

${ }^{23}$ Frans Magnis Suseno, Kuasa dan Moral, 6. 
2) Theory of Power

Theory of power argues that political power comes from the power of winning a competition. Scholars who support for this theory include Ibn Khaldun and Niccolo Machiavelli. ${ }^{24}$

c. State's Superiority over the Society

1) Social Contract

Social contract theory argues that state is a form of contract with society. John Locke and J.J. Rousseau opined that people are the rulers, and their power is obtained through natural selection. ${ }^{25}$ In line with their argument, Muslim scholar al-Mawardi has formulated a political philosophy and social contract theory. ${ }^{26}$

2) Democracy

Democracy is an evolving and dynamic concept, since the ancient Greece to the present time. In the ancient Greece, democracy was defined as "government of the people, by the people, and for the people". ${ }^{27}$ This theory continues to grow, and has become a model for both direct democracy and representative democracy.

3) Civil Society

Civil Society, or koinonia politike, refers to a situation in which the highest authority in political and economic fields is hold by the people. Civil society may also refer a group in society that is autonomous to the power of the ruling state. In terms of decision-making, the community is described as a socio-political culture that has an equal position before the law. ${ }^{28}$

${ }^{24}$ Soehino, Ilmu Negara (Yogyakarta: Liberty, 1980), 32.

${ }^{25}$ J. J Rousseou, Kontrak Sosial (Jakarta: Erlangga, 1986), 14-15.

${ }^{26}$ Al-Mawardi, al-Ahkam al-Sulthaniyah: Prinsip-Prinsip Penyelenggaraan Negara Islam (Jakarta: Daarul Falah, 2000), 1.

${ }^{27}$ Ahmad Suhelmi, Pemikiran Politik Barat, 154.

${ }^{28}$ Hans Kelsen, Teori Umum tentang Hukum dan Negara (Bandung: Nusa Media, 2011), 109. 


\section{Historical Backgrounds of Arā 'Ahl al-Madinah al-Fādilah and The City of God}

Both al-Farabi and Augustine lived at different times and different political contexts. Augustine, a prominent saint of an ancient Church, was born on Sunday, November 13, 354 in Tagaste, Algeria. ${ }^{29}$ Al-Farabi, whose full name is Abu Nasr Ibn Audah Ibn Thorban al-Farabi, was born in Wasij, Farab City (Transoxania) in $257 \mathrm{H}$ (870 AD). ${ }^{30}$ Augustine's father, Patrisius, was a landlord and a city's elder, who was considered a nonbeliever according to the Christian view. Thanks to the persistent prayer and encouragement from Monika, his wife, Patrisius took his repentance, and was baptized right before the time of his death. Augustine's mother is St. Monika, a devout Christian, who educated her three sons and daughters in the Christian faith. Augustine was a rebel teenager. He often joined naughty children of his age to create a mess that often worried their parents. ${ }^{31}$ When he was still in school age, while his parents were away, he invited his friends to take his father's favorite guava fruit behind the house. They ate all the fruit, causing his father's anger. There was also a time when he and his friends who were members of the group "7 Challengers Tagaste" stole fruits belonging to someone named Tallus, not to be eaten or offered to people but simply to be given to pigs. ${ }^{32}$

Al-Farabi is a muslim philosopher who came from Persia. His father, Muhammad Auzlagh, was a Persian soldier, and his mother was Turkish. ${ }^{33}$ Al-Farabi spent his youth in Farab, where he received his primary education. He was a smart student, mastering various branches of knowledge, understanding up to seventy languages, although only four languages were fluent, namely Arabic, Persian, Turkish, and Kurdish. At first, al-Farabi studied the Quran, grammar, literature, religious sciences (Fiqh, Tafsir, and hadith), and basic arithmetic. Later he moved to Bukhara, where he studied

${ }^{29}$ A sizoo, Augustinus, Hidupnya dan Karyanya, 1 ed. (Jakarta: BPK Gunung MUlia, 1975), 15-23.

${ }^{30}$ Y. Rumanto, "Gagasan Filsafat Politik Al-Farabi," Jurnal Driyarkara, 2003, 35.

${ }^{31}$ S. Djatimala, Augustinus Anak Petani Dari Thagaste, (Jakarta: BPK Gunung Mulia, 1966), 5-10.

${ }^{32}$ A sizoo, Augustinus, Hidupnya dan Karyanya, 25-31.

${ }_{33}$ Munawir Sjadzali, Islam dan Tata Negara; Ajaran, Sejarah dan Pemikiran (Jakarta: UI Press, 1993), 49. 
other sciences, including Persian philosophy and music. Due to request by Abu Ja'far Muhammad Ibn al-Qasim, a Wazir, in 936, al-Farabi wrote a music book, entitled Kitab al-Musiqa al-Kabïr. ${ }^{34}$

At the age of 17, Augustine traveled to Carthago to continue his study, under the financial assistance of the city's mayor, Romanianius. Like in Thagaste, Augustine in Carthago was still a rebellious teenager. He did not like to attend the churches for prayers as many of the other city dwellers did. He persisted to embrace and practic religious teachings of $\mathrm{Mani}^{35}{ }^{35}$ a religion that he had embraced since his life in Thagaste.

Augustine went to Milan, Italy, when he was twenty-nine years old. Like what he did in Carthago, he came to Milan with his firmed belief in Mani's teachings. He had read many literary books, but none had satisfied him, because they did not give him what he searched for, a peace of mind. After a short while, he began to convert to Christianity, after his intensive encounters with a charismatic Bishop Ambrose, who was a role model for the Milanese people. ${ }^{36}$ His repentance took place when he reached his 31 years of age, although he was not ready to be baptized, as he needed more time to change himself. On April 24, 387 Augustine was baptized by Bishop Ambrose, and decided to embrace a devout Christian life style, living in meditation and prayers. In 388, after his mother passed away, Augustine returned to Africa. He later was known a pious individual, donating all his wealth to the poor, as well as establishing a religious community. Four years after that he was appointed bishop of Hippo and led the conversion. ${ }^{37}$

After his conversion, Augustine, a former professor in rhetoric, became an accomplished preacher. Many people were amazed at his capability of preaching, and because of it many Catholics become more assured in holding their faith. ${ }^{38}$ Augustine wrote 218 letters, 500 sermons,

${ }^{34}$ Hermawan Heris, Filsafat Islam, (Bandung: CV. Insan Mandiri, 2011), 29.

${ }^{35}$ Manicheism is a sect in Christianity that is considered heretic due to its belief of rejecting Allah as the God, and its devotion to rationalism. This sect developed in $3 \mathrm{CE}$ Africa. Its followers were mostly landlords, rich traders, intellectuals, and a few of the poor people, See T. Kermit Scott, Augustine, His Thougt in Context (New York: Mahwah, NJ, 1995), 75-76.

${ }^{36}$ A sizoo, Augustinus, Hidupnya dan Karyanya, 59-73.

${ }^{37}$ Ibid., 74.

${ }^{38} \mathrm{Ibid}$. 
and 113 books and founded a monastery in Hippo to educate monks so that they could spread the gospel to other areas, even abroad. The Catholic Church in Africa began to grow and develop rapidly. Augustine died on 18 August 430 at Hippo at the age of 76 . His tomb is located in St. Peter's Basilica. His collection of letters, sermons, and writings is a valuable heritage of the Church.

The other figure, al-Farabi, was a judge and later a philosopher. After stopping from his work as a judge, he went to Merv to learn Aristotelian logic and philosophy. His main teacher was Yuhanna Ibn Hailan. Under his guidance, al-Farabi read the foundational texts of Aristotelian logic, including the Analytica Posteriora, which was never learned by a Muslim before.

After that, he moved to Harran, one of the centers of Greek culture in Minor Asia, in which he studied to Yuhanna Ibn Hailan. Yet only lived in the city for a quick period of time, and returned to Baghdad to learn philosophy, and studied the science of logic. He settled in Baghdad for 20 years. During that time, he spent his time composing, teaching, and reviewing philosophy books. Among his well-known students was Yahya bin Adi, a Christian philosopher. ${ }^{39}$ In $330 \mathrm{H}$ (941 AD) he moved to Damascus in which he was introduced to Saif ad-Daulah al-Hamdani, Sultan of the Hamdan Dynasty in Allepo. The Sultan asked him to become a scholar in his palace, with enormous benefits and protection. Yet, al-Farabi preferred a modest life (zuhud) and was not interested in luxury and wealth. For approximately 10 years, al-Faribi lived in Allepo and Damascus on a mobile basis. In December $950 \mathrm{AD}(339 \mathrm{AH})$, he died at the age of 80 in Damascus. ${ }^{40}$

Al-Farabi wrote many books, commentaries, and explanations of philosophical works by Aristotle, Plato, and other Greek philosophers. His review of Aristotle's thought is divided into several issues. They include 1). Burhan, or a branch in philosophy that mainly discusses about propositions; 2). ibarat, or a way of explaining things in an explanation or a writing by making parables; 3 ). khitobah, or a science that focuses on how to deliver a speech, equivalent to Christianity's homily; 4). al-jadal, or a science of how

\footnotetext{
${ }^{39}$ Sudarsono, Filsafat Ilsam, (Jakarta: Rineka Cipta, 2010), 31.

${ }^{40}$ Supriyadi Dedi, Pengantar Filsafat Islam, (Bandung: Pustaka Setia, 2009), 82.
} 
to be good at argumentations; 5). qiyas or analogy; and 6). mantiq or a science about logic. Kitab al-Majesti fi-Ihnil Falaq is his writing that contains his comments on Plotinus' works, and Maqalah Fin-nafsi is his comments on the works of Iskandar al-Dfraudisiy; not to mention his other works which are abundant. ${ }^{41}$

One of the philosophical theories constructed by al-Farabi is the emanation theory, which he drew from Plotin's thoughts. ${ }^{42}$ This theory argues that if there is a being that comes after another being, the second being is an emanation of the first being. The first being, which is called "the true One", is always still in nature. It can be likened to the sun and its rays, in which the latter comes out from the former that is always still. If the first being is still exist, it can be assured that other beings will continue to emerge, as a result of its existence.

Al-Farabi also wrote his contribution on theorizing how to improve society and its unity as a community. With regards to his philosophy of state, he was quite inspired by Plato and Aristotle, who argued that human beings are a social creature, which means that they are like to socialize with each other. Humans cannot live and are unable to fulfill their own needs by themselves. Therefore they need to live and cooperate with other humans, and in a higher level, such cooperation to living together is manifested in the form of state, in which all people are supposed to support each other in order to achieve a set of common goals such as welfare and happiness, both in this world and in the hereafter. ${ }^{43}$

Al-Farabi classified society into two types. The first is what he called al-mujtama 'al-kamilah, or the perfect society. This is a society that all of its elements are in balance. ${ }^{44}$ This society is divided into three groups: large, medium and small. A large group refers to a combination of several nations

${ }^{41}$ A. Mustofa, Filsafat Islam (Bandung: Pustaka Setia, 1999), 127-28.

${ }^{42}$ Plotinus philosophy is largely based on Plato's philosophy, despite many of his thoughts has a high level of novelty. Works of Plotinus are of significant values, not only because they have some resonances with Plato's and Aristotle's works, but because they offer sharp and detailed analyses. See for instance Ismail Asy-Syarafa, Ensiklopedi Filsafat (Jakarta: Khalifa Pustaka Al-Kautsar Grup, 2005), 58-59.

${ }^{43}$ Munawir Sjadzali, Islam dan Tata Negara; Ajaran, Sejarah dan Pemikiran, 51.

${ }^{44}$ Poerwantana, Abu Ahmadi, and Rosali, Seluk beluk Filsafat Islam (Bandung: Rosdakarya, 1988), 138. 
that agree to collaborate. A medium group refers to a community that live in one area called a country, and a small group refers to a group of people who resides in a city. ${ }^{45}$

The second society is al-mujtama 'laisa kamilah, or the imperfect society. This refers to a group of people who live in a small area such as a village and a hamlet, or even a family house. According to al-Farabi, an ideal state is a state that its components are complete, just like a human body that all of its parts are connected in a systemic and reciprocal relationship. ${ }^{46}$

Al-Farabi viewed that all citizens of a country are gifted with different potentials and capabilities. Yet, out of these citizens, there should be only one person who is elected as head of the state, whose main job is to regulate the organization of the state. The other citizens who have potentials and skills can carry out other jobs or responsibilities that support and are in line with policies that have been set by the state leader. In addition to that, the sate leader is also responsible to distribute other jobs of organizing the state, in order to reach the main goal of the state, which according to alFarabi is to create a welfare and happy society.$^{47} \mathrm{Al}$-Farabi also argued that the most appropriate character to become a state leader is either a prophet or a philosopher. This is because according to al-Farabi, a state leader is responsible not only to regulate the country, but also to educate all of its citizens so that they do not live in ignorance, and can live in happiness and enlightenment. If there is neither a prophet nor a philosopher around, then leadership of the state can be held in collective, so that the prophetic and philosophical characters of a state leader can be shared among selected people, who are deemed to have the ability to embody the prophetic traits. ${ }^{48}$ According to al-Farabi, a good state is like a healthy individual, and a bad state is like a sick individual. ${ }^{49}$

\footnotetext{
${ }^{45}$ Munawir Sjadzali, Islam dan Tata Negara; Ajaran, Sejarah dan Pemikiran, 51-
} 52.

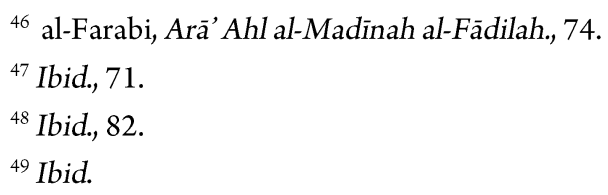




\section{Ideal State in al-Farabi's and Augustine's Perspectives}

The conception of an ideal state according al-Farabi, as stated above, is heavily influenced by Plato's and Aristotle's thoughts. He paralleled a state with a human body, which consists of various parts, all with their own tasks and functions. The highest part of a human body is the head, in which human's brain, which controls all activities, is located. Yet the brain cannot work alone, as it requires a controller, which is the heart. ${ }^{50}$ As a balance between brain and heart will create a pleasure, a state must have its objectives (ends of the state), a set of goals shared with its citizens. Therefore, al-Farabi argues, that every citizen must have their own idea or arā'u, which has to be defended for its realization, seen here as the final destination of the state, that is the shared goal, namely "happiness".

For Augustine, a discussion about state cannot be separated from a discussion about history. His knowledge in history had led him to the conclusion that history is a mystery only known and determined by God. History is a mystery of God, but at the same time God himself is a mystery. ${ }^{51}$

In his The City of God, Augustine was able to integrate philosophy and history, not to mention his success in combining philosophical findings with those of theological ones. ${ }^{52}$ The concept of universal history that he had found is a product that was finely crafted through theological and philosophical concepts, largely based on the Bible. According to Christian traditions, history would continue to move, from the moment it was created through to the moment Augustine created his works. With his concept of universal history, he became be the first person to trace back the history of every nation in the world. ${ }^{53}$

The City of God maintains two models of cities or states, which are the earthly state and the heavenly state, all with their own characteristics. ${ }^{54}$ His views on dualism, such as earthly and heavenly, temporary and eternal,

${ }^{50}$ Hasyimsyah Nasution, Filsafat Ilmu (Jakarta: Gaya Media Pratama, 2005), 41.

${ }^{51}$ Augustine, The City of God. (London: J.M. Dent \&Sons Ltd, 1950), 361; Then see N.L Geisler, "Augustine of Hippo," in Evangelical Dictionary of Theology, ed. oleh Walter E. Elwell (Baker: Grand Rapids, 1984), 106.

${ }^{52}$ J. H. Rapar, Filsafat Politik Agustinus (Jakarta: Rajawali, 1989), 43.

${ }^{53}$ W.H.C Frend, The Rise of Christianity (Darton: longman and Tood, 1984), 26.

${ }^{54}$ Augustine, The City of God., 361. 
good and evil, profane and sacred, are indeed similar to Plato's thoughts. However, studied more thoroughly, there is an ontological difference between his thoughts and those of Plato's and Augustine's, because the latter based their concept on manifest dualism, while the former on historical dualism, emphasizing a significance difference between their thoughts. ${ }^{55}$

At the end of his The City of God, Augustine talked about the end of human's worldly journey. He divides the world history into three periods: the period before the law, the period within the application of law, the period of grace after the law. Augustine's explanation is analogous to human growth, childhood, adulthood, and old age, a parable that was intended to explain a historical development from time to time. This description also indicates that time is moving towards an end or the stopping point. $\mathrm{He}$ argued that humans and the earth were currently in the third period, in which God had sent Jesus the Christ to humanity, to give the later a chance to dissolve their sins, and to bring to them their salvation. The earthly city was bound to end but the City of God would not perish.

Augustine's concept on the "ending of the earthly city" (civitate terrena) is at odds with the myth of "Roma Aeterna", or the eternity of the Roman empire. Before the publication of Augustine's The City of God, there has been a widespread belief that the city of Rome was Dominus et Deus, or the embodiment of God. The consequence of this belief is that there was an assumption that God manifestation was also eternal, thus it will not perish since as such would only reduce the greatness of God. Another assumption was that the city of Rome was sheltered by Gods, who supervised and guarded the lives of Roman people. This had resulted to a feeling of superiority among the Romans over people of other nations. For Augustine, however, the fall of Rome should be interpreted that Rome was no different from any other cities, and the belief of Rome's eternity was a false. Thus, if the people of Rome committed a sin and evil behavior, so much as the shackles of the devil were broken and had defeated the power of angels; the Rome would nevertheless come to its destruction. ${ }^{56}$

When living their lives, human beings are face with both the way of God and the way of the demon. Yet, the choice remains on the hands of the

\footnotetext{
${ }^{55}$ Augustine, 227; compare with Augustine, 273.

${ }^{56}$ Augustine, The City of God., 92.
} 
humans. Both ways will lead to different and opposing goals. The way of God will lead the humans to the "state of God" and the way of the demon will lead the humans to the kingdom of evils. The state of god is made up of saints, while the state of evil is made up of wicked people. At the moment, the two "states" physically co-exist, despite their views are separated. On the Day of Judgment, however, the two states will also separate physically. ${ }^{57}$

Slightly different from Augustine, al-Farabi was aspired to the idea of creating an international world order with a single universal institution, as an example of an ideal state, which he called al-Madinah al-Fãdilah, and as a response to Plato's and Aristotle's ideas of a perfect state, that is, the state that is led by a philosopher. A good state according to al-Farabi must spread divine values that aim to attain mutual, material, and spiritual happiness under the control of a leader and his representatives, who have prophetic characteristics. In addition, that state has to be supported by its citizens, whose way of thinking and work is based on cooperating principles.

Al-Farabi divides state into five types. The first is what he called alMadinah al-Fādilah, or the ideal state. It refers to a state that has a clear goal, that is, happiness, at which all elements of the state aim to achieve. The second is what he called al-Madinah al-jahiliyah, or the ignorant state. It refers to a state that has no ideology and no common goal among its citizens. This type of state is divided by al-Farabi into five categories: a) al-Madinah al-Dharuriyah, an emergency state; b) al-Madinah al-Baddalah, an evil state; c) al-Madinah al-Khissah wa al-Siqut, a despicable state; d) al-Madinah alKarimah, a respectable state, and e) al-Madinah al-Jamaiyyah, a communist state.

The third is al-Madinah al-Fasiqah. It can be defined as a state that has been damaged by its leaders and citizens due to their wicked behaviors. A state of this kind consists of citizens who understand very well the importance of happiness, virtues, and security, yet their behavior is inconsiderate and ignorant, as there is no consistency between what they said and did. ${ }^{58}$

\footnotetext{
${ }^{57}$ Augustine, Augustinus de Cathechizandis Rubidus, trans. oleh Van den End (Jakarta: BPK Gunung Mulia, 1999), 58.

${ }^{58}$ al-Farabi, Arā’ Ahl al-Madīnah al-Fādilah., 133.
} 
The fourth is al-Madinah al-Mubaddilah, or a state that is in decline. In the beginning, all leaders and citizens living in this state were of good behavior, just like those living in the ideal state. Yet, due to the coming of negative influences from the outside world, they failed to maintain their positive characteristics. ${ }^{59}$ The fifth is al-Madinah al-Dalalah. It refers to a state that is inhabited by those who misjudge about God and life, yet their leaders claimed themselves as the true representative of God the leader assumes that he is a representative of God. ${ }^{60}$

\section{E. Some Similarities in al-Farabi's and Augustine's Concepts of the Ideal State}

Based on the explanation above, it can be argued that there are some similarities between al-Farabi's and Augustine's concepts of the ideal state. They are the followings. First, al-Farabi's and Augustine's writings could not be separated from political contexts of their times. These contexts, in fact, became a source of inspiration for both of them to write their theory about state. Second, both of them had their concerns about political problems that happened in their times, and by writing their ideas about the state, they attempted to offer alternative solutions to overcome those problems, hoping that their works could make a difference for a better life. Third, both alFarabi and Augustine were never directly involved in state governance and bureaucracy. What they offered was their thoughts as philosophers. Thus, critics of their theories are often directed at the fact that they are not based on the first-hand experience of managing a state, and that their theories were not empirically tested by their current political situations.

Fourth, both al-Farabi and Augustine called forth the importance for a state to have noble goals. What they meant by noble goals is not only in terms of material prosperity, but also psychological and spiritual well beings: the combination of which is called by them as the true happiness. A state that can meet the physical needs of its citizens cannot be said to have led its people to be happy, because happiness does not only lie in material wealth but also immaterial needs. This is where the importance of state ethics. Fifth,

\footnotetext{
${ }^{59}$ Ibid,.

${ }^{60}$ Abdul Wahid Wafa, Al-Madînah al-Fādilah li al-Farabi, (Kairo: Alam Kutub,
} 1973), 78. 
al-Farabi and Augustine realized that religion has a central role in providing boundaries and guidelines. Religion provides guidance for human beings, so that they can behave appropriately: because transgression will inevitably lead to distortion.

Sixth, both al-Farabi and Augustine were concerned about morality of their societies. Augustine's questions about morality had led him to a dynamic and dramatic life adventure, which led him to abandon his Christian faith. Al-Farabi, involved in philosophical works, had witnessed a moral chaos among members of society of his time, which led him to writing his thought on the ideal state.

Seventh, both al-Farabi and Augustine shared the view that a state has a goal, that is, to spread divine values aimed at creating material and spiritual prosperity, which is called happiness. Eighth, al-Farabi and Augustine emphasized professionalism in managing the state because the leader is responsible for social welfare. To govern a state does not only need knowledge and skills, but also a deep spiritual morality. The last point that I wanted to emphasize here is related to the relevance of their thoughts on the ideal state to the contexts of contemporary Indonesia. In the political situation faced by Augustine and al-Farabi, where the state has lost its orientation, the concept of an ideal state is needed for revitalization and upgrading of state administration. In contemporary multi-parties Indonesia, which tends to develop towards liberal thinking and absolute materialism, it is needed to call for the importance of reviving our local noble values that are based on religions.

\section{F. Conclusion}

Al-Farabi and Augustine's thoughts about an ideal state share several similarities. They can be summarized as follows. An ideal state (1) must have noble objectives, (2) base its rules of law and their implementation on religious values, and (3) social norms and public morality that are respected by its citizens and leaders alike.

In social life, it is necessary to look for a common ground, rather than differences. This effort can be made by enhancing a dialogical approach between adherents of religions, in order to establish a religious harmony in its true meaning. [] 
Sudarman

\section{References}

Augustine, Augustinus de Cathechizandis Rubidus. Diterjemahkan oleh Van den End. Jakarta: BPK Gunung Mulia, 1999. , The City of God. London: J.M. Dent \&Sons Ltd, 1950.

Aziz, Abdul, Chiefdom Madinah: Salah Paham Negara Islam. Jakarta: Pustaka Alfabet, 2011.

Bakri, Syamsul, “Agama, Persoalan Sosial, dan Krisis Moral.” Komunikasi : Jurnal Dakwah dan Komunikasi 3, no. 1 (t.t.): 42.

Budiarjo, Miriam, Dasar-dasar Ilmu Politik. Jakarta: Gramedia, 2001.

Budiman, Arief, Teori Negara: Negara, Ideologi dan Kedaulatan. Jakarta: Gramedia, 1996.

Djatimala, S., Augustinus Anak Petani Dari Thagaste. 2 ed. Jakarta: BPK Gunung Mulia, 1966.

Drajat, Amroeni, Suhrawardi: Kritik Falsafah Parepatetik. Yogyakarta: LKiS, 2005.

al-Farabi, Abu Nashr Muhammad bin Muhammad bin Tarkhan bin Auzalagh, Arā' Ahl al-Madīnah al-Fādilah. Mesir: al-Azhar, t.t.

Frend, W.H.C., The Rise of Christianity. Darton: longman and Tood, 1984.

Geisler, N.L., "Augustine of Hippo." in Evangelical Dictionary of Theology, Walter E. Elwell (ed), 106. Baker: Grand Rapids, 1984.

Hasani, Ismail, "Paradoks Konstitusional Jaminan Kebebasan Beragama/Berkeyakinan." Mimbar: Jurnal Agama dan Budaya 26, no. 3 (2009): 385.

Heris, Hermawan, Filsafat Islam. 1 ed. Bandung: CV. Insan Mandiri, 2011.

Hutchinson, Gladstone \& Schumacher, Ute, "Government Policy and Human Development Evidence from Developping Countries", Journal of Third World Studies, Volume XII, no. 2, 1995.

Inson and Ute Schumacher. "Government Policy and Human Development Evidence from Developing Countries." Journal of The Third World Studies XII, no. 2 (1995): 247.

Justo, Gonzales L., A History of Christian Thought. Nashville: Abingdon, 1971. 
Kansil, C.S.T., Ilmu Negara Umum dan Indonesia. Jakarta: Pradnya Paramita, 2001.

Kelsen, Hans, Teori Umum tentang Hukum dan Negara. Bandung: Nusa Media, 2011.

al-Maududi, Abul A'la, Nazhariyyah Al-Islam Al-Siyasiyyah. Kuwait: Maktabah al Manar, t.t.

al-Mawardi, al-Ahkam al-Sulthaniyah: Prinsip-Prinsip Penyelenggaraan Negara Islam. Jakarta: Daarul Falah, 2000.

Mustofa, A., Filsafat Islam. Bandung: Pustaka Setia, 1999.

Nasution, Hasyimsyah, Filsafat Ilmu. Jakarta: Gaya Media Pratama, 2005.

Natsir, Muhammad, Agama dan Negara dalam Perspektif Islam. Jakarta: Dewan Dakwah Islamiyah Indonesia, 2001.

Poerwantana, Abu Ahmadi, and Rosali. Seluk beluk Filsafat Islam. Bandung: Rosdakarya, 1988.

Rapar, J. H., Filsafat Politik Agustinus. Jakarta: Rajawali, 1989.

Robert M. Maclver. The Modern State. London: Oxford University Press, 1955.

Rousseou, J.J., Kontrak Sosial. Jakarta: Erlangga, 1986.

Rumanto, Y., “Gagasan Filsafat Politik Al-Farabi.” Jurnal Driyarkara, 2003, 35.

Scott, T. Kermit. Augustine, His Thougt in Context. New York: Mahwah, NJ, 1995.

Sizoo, A., Augustinus, Hidupnya dan Karyanya. Jakarta: BPK Gunung Mulia, 1975.

Sjadzali, Munawir, Islam dan Tata Negara; Ajaran, Sejarah dan Pemikiran. Jakarta: UI Press, 1993.

Soehino, Ilmu Negara. Yogyakarta: Liberty, 1980.

Soltau, Roger H., An Introduction to Politics. London: longmans, 1961.

Sudarsono, Filsafat Ilsam. Jakarta: Rineka Cipta, 2010.

Suhelmi, Ahmad, Pemikiran Politik Barat. Jakarta: Gramedia, 2007.

Supriyadi, Dedi, Pengantar Filsafat Islam. 1 ed. Bandung: Pustaka Setia, 2009.

Suseno, Frans Magnis, Kuasa dan Moral. Jakarta: Gramedia, 2000. 
Sudarman

, Frans Magnis, Pijar-Pijar Filsafat, dari Gatholoco ke Filsafat Perempuan, dari Adam Muller ke Post Modernisme. Yogyakarta: Kanisius, 2005.

al-Syarafa, Ismail, Ensiklopedi Filsafat. Jakarta: Khalifa Pustaka Al-Kautsar Grup, 2005.

Wafa, Abdul Wahid, Al-Madînah al-Fâdlilah li al-Farabi. 2 ed. Kairo: Alam Kutub, 1973.

Walzer, Richard, "Greek into Arabic: Essays on Islamic Philosophy," the School of Oriental and African Studies, 1962.

Weber, Max, Gerth, Hans Heinrich, and Mils, C. Wright, From Max Weber: Essays in Sociology. New York: Oxford University Press, 1955. 